\title{
PERFORMANCE PRODUCTION OF STRAWBERRY IN ENVIRONMENT CULTIVATED WITH FIG TREE
}

\author{
HELOISA FERRO CONSTÂNCIO MENDONÇA², EUNICE OLIVEIRA CALVETE ${ }^{3}$, \\ ROSIANI CASTOLDI DA COSTA ${ }^{4}$, ALEXANDRE AUGUSTO NIENOW ${ }^{5}$
}

\begin{abstract}
The use of protected environment in horticulture has been increasingly used as it provides increased precocity and productivity, in addition to produce outside the normal growing season. Both woody species such as herbs are possible to cultivate in this environment. However fruit plants occupy large spaces with a short production period. The study aimed to test whether strawberry genotypes present different production peaks in cultivated environment with fig trees. The treatments consisted of strawberry cultivars Aromas, Albion, Camino Real, Camarosa and Ventana distributed in delineation of randomized blocks with four replications and with a population of 10 plants $\mathrm{m}^{-2}$. It was recorded precocity in cultivars Albion, Camarosa and Ventana, because they started flowering at 63 days after planting. Aromas and Camino Real were characterized as late. Aromas achieved greater total number of fruit, but with a lower percentage of commercial fruits in relation to the other cultivars. Peak production for all cultivars was found when there was an accumulation $2008{ }^{\circ} \mathrm{C}$ day ${ }^{-1}$, corresponding to the month of November. There were differences in performance production between strawberry cultivars conducted in the environment with fig tree, with different production peaks.
\end{abstract}

Index terms: Fragaria $\mathrm{x}$ ananassa Duch., phenology, fruit production, crop integration.

\section{DESEMPENHO PRODUTIVO DE MORANGUEIRO EM AMBIENTE CULTIVADO COM A FIGUEIRA}

RESUMO - O emprego do ambiente protegido na horticultura vem sendo cada vez mais utilizado, pois proporciona aumento da precocidade e da produtividade, além da produção fora de época normal de cultivo. Tanto as espécies lenhosas como as herbáceas são possíveis de cultivar nesse ambiente. Entretanto, plantas frutíferas ocupam grandes espaços com um período curto de produção. O trabalho teve como objetivo testar se genótipos de morangueiro apresentam picos de produção diferenciados em ambiente cultivado com figueira. Os tratamentos constituíram-se das cultivares de morangueiro Aromas, Albion, Camino Real, Camarosa e Ventana distribuídas em delineamento de blocos ao acaso, com quatro repetições e com uma população de $10 \mathrm{pl} \mathrm{m}^{-2}$. Registrou-se precocidade nas cultivares Albion, Camarosa e Ventana, pois iniciaram a floração aos 63 dias após o plantio. Aromas e Camino Real caracterizaram-se como tardias. Aromas alcançou maior número total de frutos, porém com menor porcentagem de frutos comerciais em relação as outras cultivares. O pico de produção para todas as cultivares verificou-se quando ocorreu acúmulo de 2008 ${ }^{\circ} \mathrm{C}$ dia $^{-1}$, o que correspondeu ao mês de novembro. Houve diferenças no desempenho produtivo entre as cultivares de morangueiro conduzidas no ambiente com a figueira, com distintos picos de produção.

Termos para indexação: Fragaria x ananassa Duch., fenologia, produção de frutos, integração de cultivos.

\footnotetext{
${ }^{1}$ (Paper 019-16). Received January 26, 2016. Accepted May 03, 2016.

${ }^{2}$ Agr. Eng. Master in Agronomy by the Graduate Program in Agronomy - PPGAgro of the Faculty of Agronomy and Veterinary Medicine - FAMV, University of Passo Fundo - UPF. E-mail: helo_fcmendonca@hotmail.com ${ }^{3}$ Prof. Dr. of the Agronomy Course of FAMA and PPGAgro of UPF. E-mail: calveteu@upf.br ${ }^{4}$ Dr. in Agronomy by the PPGAgro of the UPF FAMV. Email: rosianicastoldi@yahoo.com.br ${ }^{5}$ Prof. Dr. of the Agronomy Course of the FAMV and PPGAgro of the UPF. E-mail: nienow@upf.br
} 


\section{INTRODUCTION}

Protected cultivation is used to increase productivity and add value and income to agricultural products. This system has proven to be a viable alternative, especially for flowers, ornamental plants and vegetables. Both woody and herbaceous species are possible to grow in this environment. However, the high cost of investment, the lack of technical knowledge to handle crops under these conditions, the habit of growing certain species, the low planting density and consequently the low economic return, as well as the technical management of the environment itself have restricted use of this technique mainly in fruit.

In the case of fig tree, cultivation in agricultural greenhouses makes the cost of production high because the harvest period is very small. Although it was verified that the harvest period of the fig tree was increased in 2.5 to 3 months, in relation to the cultivation in an uncovered environment (NIENOW et al., 2006), the return is low in relation to the production cost.

Cultivation of fig tree (Ficus carica L.) has shown a slight global expansion due to its peculiarities as to the rusticity and adaptability to the most diverse climatic conditions, the possibility to destine the production to the market of fresh fruit or to the industrial processing and, in Brazil, exporting fruits in the off-season of producing countries of the Northern Hemisphere (DANELUZ et al., 2009).

However, strawberry cultivation in a protected environment is widely used because it provides early and out-of-season production supplying demand with soilless cultivation which, besides these possibilities, increases plant density and yield per area (MENDONÇA et al., 2010).

The peak production for strawberry cultivars produced in Brazil varies according to the genotype. In the case of cv. Camarosa we observed a superiority of $30 \%$ in relation to the others, and accumulated $20 \%$ of its production in the first half of November (ANTUNES and REISSER JÚNIOR, 2007). Variations found among cultivars are mainly due to the specific response of each genotype to temperature, photoperiod and interaction between these two factors (DROWO, 1936).

The hypothesis of this study is that the productive performance in the strawberry is not impaired when grown next to fig tree, since it begins the dormant period (leaf fall) in May extending to the beginning of August when drastic pruning is realized and starts budding. Considering that the strawberry is planted in the fig dormancy period when the luminosity is not impaired, extending its cycle until the middle of December, it is assumed that the radiation restrictions can occur only in the final third of the strawberry production, not interfering with productivity. It is also important to consider that the harvesting periods of these two fruit are complementary which allows the consortium of these two crops and intensifies the use of the protected environment that has a high cost. To answer these questions, a study was carried out to test whether strawberry genotypes present differentiated production peaks in an environment cultivated with fig trees.

\section{MATERIAL AND METHODS}

Plant material and location of the experiment

We used seedlings of the strawberries cultivars Aromas, Albion (Neutral Days-ND), Camino Real, Camarosa and Ventana (Short Days$\mathrm{SD}$ ), from the LLAHUEN greenhouse which is located in the Chilean Patagonia (33 ${ }^{\circ} 50^{\prime} 15.41^{\prime \prime} \mathrm{S}$ and $70^{\circ} 40^{\prime} 03.06^{\prime \prime} \mathrm{O}$ ) and whose seedlings were provided by the Improvement Program of the University of California. The multiplication of seedlings from the matrices is performed in open field after soil sterilization at a spacing of $27 \mathrm{~cm}$ per plant $(62,000$ plants $\left.\mathrm{ha}^{-1}\right)$. After two months of planting the commercial seedlings are harvested mechanically and prepared by washing and selection (crown diameter). The seedlings are packaged without leaves and sent to Brazil in containers transported by ships and delivered after quarantine of 10 to 12 weeks.

The experiment was carried out in a protected environment in the Horticulture Sector of the Passo Fundo University, in Passo Fundo, RS, where geographical coordinates are: latitude $28^{\circ} 15^{\prime} 41^{\prime \prime} \mathrm{S}$, longitude $52^{\circ} 24^{\prime} 45^{\prime \prime} \mathrm{W}$ and average altitude of 709 $\mathrm{m}$. The average annual of chilling hour is $422 \mathrm{~h}$, with temperatures lower or equal to $7.0^{\circ} \mathrm{C}$. In general, they vary from $214 \mathrm{~h}$ to $554 \mathrm{~h}$ (CUNHA, 2003).

\section{Treatments and experimental design}

Aromas, Albion, Camino Real, Camarosa and Ventana strawberry cultivars (treatments) were transplanted on June $3^{\text {rd }}, 2009$ in bags filled with commercial substrate composed of composted and sterilized organic vegetable matter, peat and vermiculite, distributed horizontally on the ground next to the fig tree cultivar Roxo de Valinhos (Figure 1A). The experimental design was randomized blocks with four replications and 10 plants per plot, being considered 6 useful plants for the evaluation. The plant population was 10 plants $\mathrm{m}^{-2}$. 


\section{Procedures}

The fig tree was implanted in August 2000. In the pruning, during the previous 8 years of cultivation a segment per branch (around $5 \mathrm{~cm}$ ) of the previous year was left as recommended by Dalastra et al. (2011) and Campagnolo et al. (2010). In the year of the experiment, the rejuvenation pruning (Figure 1B) was performed on August $18^{\text {th }}, 2009$. After the beginning of the sprouting, nitrogen fertilizations were carried out by fertirrigation in the amount of $45 \mathrm{~g} \mathrm{plant}^{-1}$. The fig plants were conducted at a spacing of $0.75 \mathrm{~m}$ in the line with four branches and at $1.50 \mathrm{~m}$ with eight branches, spaced at $1.90 \mathrm{~m}$ between rows and density of 28,070 branches $\mathrm{ha}^{-1}$. In the strawberry the irrigation was performed by a drip system, composed of fixed hoses inside the bags with spacing between drippers of $30 \mathrm{~cm}$. For the fertigation three nutrient solutions were prepared according to the fruit stage and according to the recommendations described by Calvete et al. (2007).

To increase pollination in the strawberry cultivars a swarm of Apis mellifera was placed positioned externally along the side with the opening of the box to the inside and the outside of the greenhouse.

During the experiment the following morph physiological evaluations were performed on the strawberry cultivars.

\section{Phenology}

The cycle was determined through the beginning and duration of flowering, fruiting and maturation, and beginning and end of harvest.

\section{Production}

\section{Income Components}

In the production were evaluated the number and the total fresh and commercial mass of fruits per plant $\left(\mathrm{g} \mathrm{plant}^{-1}\right)$; total fresh commercial fruit mass $(\mathrm{g})$ and percentage of commercial fruits. Commercial fruits were those with more than $6 \mathrm{~g}$, devoid of injuries, diseases and deformations. The fruit were harvested when presented 3/4 mature to fully mature.

\footnotetext{
Cultivar production relation with temperature and photoperiod in the greenhouse

In the environment the temperature (Figure 2A), the photosynthetically active radiation (Figure 2B) and the photoperiod were monitored. The photosynthetically active radiation was recorded through a sensor and read through the ProCheck apparatus performed on typical open sky days and cloudy sky days, monthly, from June to January 2009. The air temperature was measured using a term
}

hygrograph weekly recorded of Sato brand, installed at a height of $1.50 \mathrm{~m}$ inside the greenhouse.

The mean daily temperature (Tmd) was calculated by the following equation that calculates the arithmetic mean of the temperatures $\left({ }^{\circ} \mathrm{C}\right)$ recorded by the thermos hygrograph every two hours during the whole day:

$$
T m d=\frac{t 0+t 2+t 4+\cdots+t 18+t 20+t 22}{12}
$$

The daily thermal sum (TSd) was calculated by the following formula:

$$
T S d=(T m-T b) \quad\left\{{ }^{\circ} C d a y^{-1}\right\}
$$

The base temperature $(\mathrm{Tb})$ is defined as the minimum temperature below which there is no emission of leaves, assuming $\mathrm{Tb}$ of $7^{\circ} \mathrm{C}$. The TSd was accumulated from the transplant of the seedlings, resulting in the accumulated thermal sum (TSa), that is:

$$
T S a=\Sigma T S d
$$

The photoperiod $(\mathrm{N})$ was calculated based on the hourly sunrise angle (hn) using the formula:

$$
N=2 \times h_{n} \div 15^{\circ}
$$

The photoperiod depends on the latitude $(\Phi)$ and the solar declination $(\delta)$, which are in the following equation to calculate the photoperiod:

$$
h_{n}=\arccos \times[-\tan \Phi \times \tan \delta]
$$

The solar declination $(\delta)$, uses for the calculation the number of the day in the year (NDY), which is calculated by the equation:

$$
\delta=23.45 \times \sin [360(N D Y-80) \div 365]
$$

\section{Productive performance}

The productive performance was calculated considering the percentage of fruits accumulated in biweekly crops from August 2009 to January 2010, in relation to the total harvested.

\section{Data analysis}

The results obtained from the strawberry cultivars were submitted to analysis of variance by the $F$ test and when there was significance difference between averages were compared by the Tukey test at $5 \%$ error probability using the CoStat statistical program (COHORT SOFTWARE, 2003). 


\section{RESULTS AND DISCUSSION}

\section{Phenology}

The Albion, Camarosa and Ventana cultivars were recorded precocity, since they started flowering at 63 days after planting (DAP) (Figure 3). Aromas and Camino Real were characterized as late, since the harvest started 10 days after Camarosa and Albion and 6 days after Ventana. Variations found among cultivars are mainly due to the specific response of each genotype to the temperature, to the photoperiod and to the interaction between these two factors (DROWO, 1936) and this explains why the genotype versus environment interaction causes distinct phenotypic expressions. Phenology is defined as the branch of ecology that studies the external periodic phenomena of living beings through systematic observations and records of these phenomena. These are influenced by two types of conditions: intrinsic (specific of the species or variety) and extrinsic (dependent on the environmental conditions). In the strawberry, flowering is conditioned by the genetic characteristics of each cultivar and by the temperature and photoperiod interaction (BRANDFORD et al., 2010).

Traditionally strawberry cultivars have been classified in relation to flowering by photoperiodic responses in plants of Short Days (SD), Long Days (LD) plants and insensitive to photoperiod as Neutral Days (ND) (SØNSTEBY and HEIDE, 2008). Photoperiod between 8 and $11 \mathrm{~h}$ are required for floral induction in SD cultivars, a situation that usually occurs in late summer and in the fall and winter. However, floral induction in SD cultivars is a physiological process with optional control, since they induce flowering when the temperature is higher than $15^{\circ} \mathrm{C}$ while at lower temperatures these form floral buds independent of the photoperiod (SØNSTEBY and HEIDE, 2007). Already at high temperatures the decrease of flowering occurs. Those considered neutral, more specifically, require temperatures below $10^{\circ} \mathrm{C}$ for flowering (NISHIYAMA and KANAHAMA, 2000; SØNSTEBY and HEIDE, 2007).

It can thus be deduced that a rigid classification of strawberry cultivars is not possible. Therefore, the cultivars Camarosa Ventana and Camino Real, in the present study, ranged from obligatory shortday plants to optional short-day plants. Aromas and Albion were expressed as neutral only when temperatures were below $10^{\circ} \mathrm{C}$ (HANCOCK et al., 2002). The minimum and maximum absolute temperatures within the protected environment during the cycle of the strawberry cultivars ranged from $-6.6^{\circ} \mathrm{C}$ to $42^{\circ} \mathrm{C}$. It was registered 21 days of minimum temperatures equal or less than $5^{\circ} \mathrm{C}$ and average temperature of $15.5^{\circ} \mathrm{C}$ inside the protected environment (Figure 2A).

\section{Production}

\section{Income component}

The five cultivars intercropped with fig tree are different in total number of fruits and commercial fruits (Table 1). Aromas reached higher total number of fruits, but these showed with lower percentage of commercial fruits in relation to the other cultivars.

The productivity found in Aromas $(467.4 \mathrm{~g}$ ) is comparable to that obtained in Minas Gerais /Brazil (401.78 g plant $^{-1}$ ) (GUIMARÃES et al., 2015), but differs from the results obtained in the region of Pelotas-RS $1 \mathrm{~kg}$ per plant) (OLIVEIRA et al., 2007). The lower productivity reported in this study in relation to the Pelotas region can be attributed to the difference in methodology used. In Pelotas region the transplant was performed within the recommended period for the southern region (AprilMay), while in this experiment there was a delay in one month (June). It must be considered that they are different cropping systems. When grown in the soil the productivity is higher, because it provides more balance to the plant, mainly in relation to the temperature variation. For the reported results in this study the cultivars were conducted on substrate

\section{Cultivar production relation with the} temperature, and the photoperiod in the greenhouse.

The peak of production for all cultivars was verified when there was accumulation of $2008{ }^{\circ} \mathrm{C}$ day ${ }^{-1}$ which corresponded to the month of November (Figure 4A). These data agree with the peak of production found by other authors, corresponding to the first half of November (ANTUNES and REISSER JÚNIOR, 2007). Ventana started its harvest producing more than the other cultivars $\left(105 \mathrm{~g} \mathrm{plant}^{-1}\right)$, but did not reach high production peaks. This result was related to its precocity (Figure 3 ). Camarosa was different from the other cultivars in relation to the peak of production being more extensive and lasting in the months of November (125.9 $\mathrm{g} \mathrm{plant}^{-1}$ ) and December $\left(116.8 \mathrm{~g} \mathrm{plant}^{-1}\right)$. It is interesting to show that this cultivar presented similar phenology to Ventana (Figure 3), but with differences in relation to the peak of production reinforcing Camarosa's productive capacity.

All produced genotypes were with a thermal sum between 1000 and $3000^{\circ} \mathrm{C}$ day $^{-1}$. The production of the cultivars was reduced when the photoperiod reached 13 and 14 hours (Figure 4B) and the average 
air temperature reached $27^{\circ} \mathrm{C}$ (Figure $4 \mathrm{~A}$ ) being more evident in the cultivars of Short days. These results agree with Verheul et al. (2006) where it is clarified that for cultivars of SD (Korona cv.) produced in greenhouses, in addition to the interaction photoperiod $\mathrm{X}$ temperature, the emergence and development of flowering can be controlled with precision by the adjustment of the photoperiod and the nighttime temperature; by the period in which the plant remains in SD and by the age of the plant grown under greenhouse conditions. Considering the cultivars of neutral days, the studies referring to their physiological behavior are still incipient, but the literature indicates that temperature above $28^{\circ} \mathrm{C}$ decreases or paralyzes the flowering in these cultivars and consequently the production. Specific studies on temperature at flowering reinforces that under $30^{\circ} \mathrm{C} / 25^{\circ} \mathrm{C}$ day and photoperiod of 8 hours of light inhibit floral induction (NISHIYAMA and KANAHAMA, 2002) and these results agree with Kadir et al. (2006), in addition to the temperature effect on flowering the genotype factor. The cultivars classified as ND generate doubts in their denomination, because they vary in the degree of flowering, depending on the place and year of cultivation, as previously explained.

\section{Productive performance in strawberry cultivars during the harvest period. \\ There are differences in productive} performance between strawberry cultivars conducted in the environment with fig tree with distinct peaks of production (Figure 5). The highest harvest percentage occurred in November with the cultivars Camino Real with $20 \%$ in the first fortnight and Albion with $16 \%$ in the second fortnight (Figure 5).

From this peak the cv. Camino Real decreased fruit production until the end of the harvest, while Albion declined until December and returned to increase its production in the first half of January. Albion is classified as ND cultivar with that the increase of the photoperiod may have benefited the increase in the production (SØNSTEBY and HEIDE, 2007).

The results indicated that strawberry production in protected environment integrated to fig tree can reduce the high costs invested in the construction of this environment, obtaining profitability in the off season. The production of figs in this environment begins at the end of December and may extend until mid-May, while the strawberry is only transplanted in the area on the end of May, extending its production until January. This deduction is based on the equivalence between the average yield per plant of $427.3 \mathrm{~g}$ obtained between the cultivars in this environment and those obtained in a single system with $395.6 \mathrm{~g}$ (MENDONÇA, 2011). Also, with respect to radiation, the average recorded within the environment was $873.0 \mathrm{mmol} \mathrm{m} \mathrm{m}^{-2} \mathrm{~s}^{-1}$, remaining within the ideal range considered for the strawberry crop development.

The integrated system between fruit and vegetable crops is innovative, with few references of this system in Brazil. Research institutions have developed studies on the production of fruits, vegetables and irrigated grains in integrated systems such as consortia, in order to provide the farmer with another source of income, as long as there is no fruit harvest previously established.

It is inferred the possibility of integrating strawberry with fig tree in addition to staggering the production of strawberry due to the performance of the different cultivars, providing harvest in periods of low supply of fruits to the market and with that increasing the income per farmer's area. 

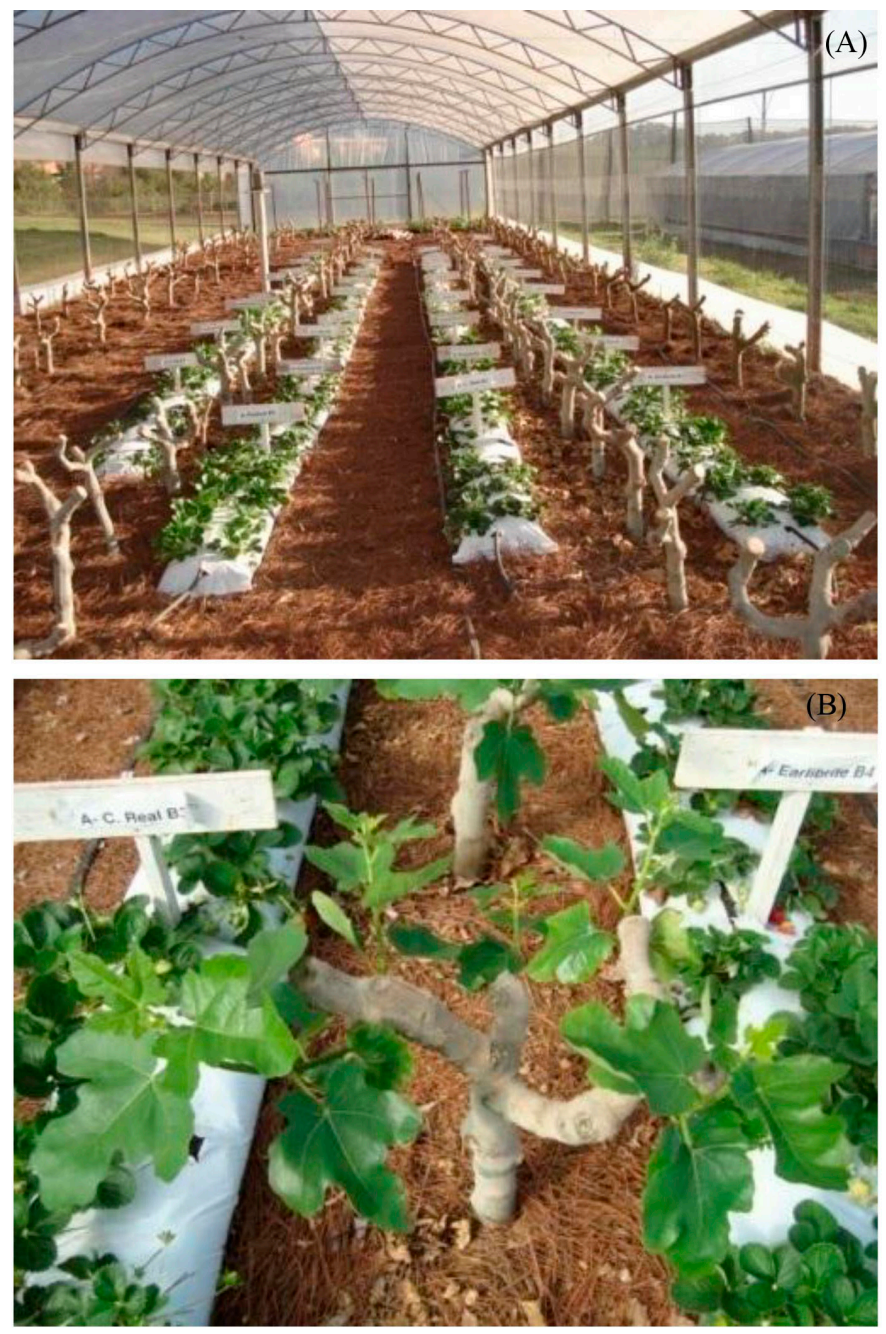

FIGURE 1- Layout of the treatments next to the fig tree (A) and details of the pruning on the fig tree (B).

TABLE 1 - Number and total fresh commercial mass of fruits per plant, and percentage of commercial fruits of five strawberry cultivars intercropped with fig tree, in protected environment, Passo Fundo, 2009/2010 cycle.

\begin{tabular}{|c|c|c|c|c|c|}
\hline \multirow{3}{*}{ Cultivars } & \multicolumn{2}{|c|}{ Number of fruits } & \multirow{3}{*}{$\begin{array}{c}\text { Commercial fruits } \\
(\%)\end{array}$} & \multicolumn{2}{|c|}{ Fresh Fruit Mass } \\
\hline & Total & Commercial & & Total & Commercial \\
\hline & \multicolumn{2}{|c|}{$\left(\right.$ plant $\left.^{-1}\right)$} & & \multicolumn{2}{|c|}{$\left(\right.$ g plant $\left.^{-1}\right)$} \\
\hline Aromas & $45.9 \mathrm{a}^{*}$ & $36.2 \mathrm{~ns}$ & $78.9 \mathrm{c}$ & $539.9 \mathrm{~ns}$ & $467.4 \mathrm{~ns}$ \\
\hline Albion & $27.8 \mathrm{~b}$ & 26.2 & $94.1 \mathrm{a}$ & 431.0 & 421.4 \\
\hline Camino Real & $27.0 \mathrm{~b}$ & 25.0 & $92.6 \mathrm{a}$ & 401.5 & 386.3 \\
\hline Camarosa & $40.7 \mathrm{ab}$ & 34.7 & $85.1 \mathrm{bc}$ & 499.9 & 457.6 \\
\hline Ventana & $27.9 \mathrm{~b}$ & 24.9 & $89.2 \mathrm{ab}$ & 419.2 & 404.1 \\
\hline Average & 33.9 & 29.4 & 87.8 & 458.3 & 427.3 \\
\hline $\mathrm{CV} \%$ & 22.5 & 23.8 & 3.7 & 23.7 & 24.0 \\
\hline
\end{tabular}

* Averages followed by the same lowercase letter vertically do not differ by the Tukey HDS. ns Not significant by variance analysis. 

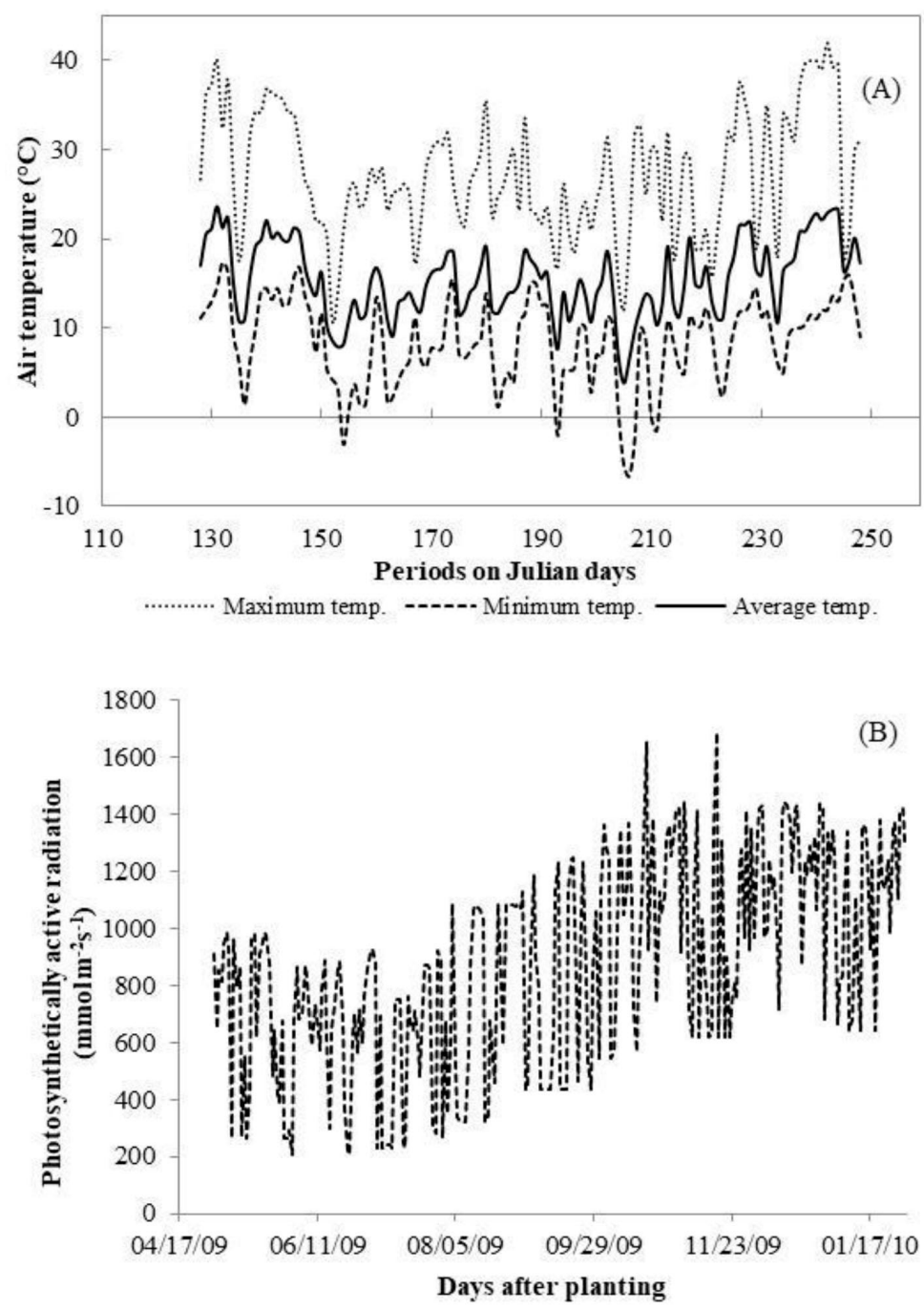

FIGURE 2 - Maximum, average and minimum air temperatures (A) recorded in the protected environment from the transplant of strawberry seedlings to the beginning of second flowering and photosynthetically active radiation $\left(\mathrm{mmol} \mathrm{m}^{-2} \mathrm{~s}^{-1}\right)(B)$, Passo Fundo, 2009.

Julian calendar

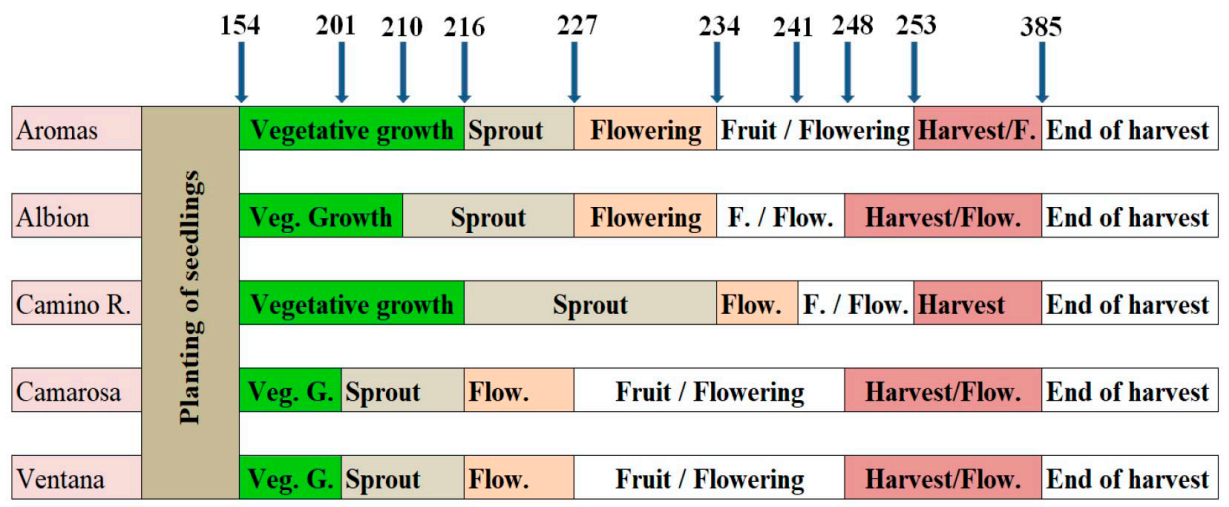

FIGURE 3 - Phenological stage of strawberry cultivars multiplied in Chile and intercropped with fig tree from the planting of the seedlings until the end of the harvest according to the Julian calendar. Passo Fundo, cycle 2009/2010. 

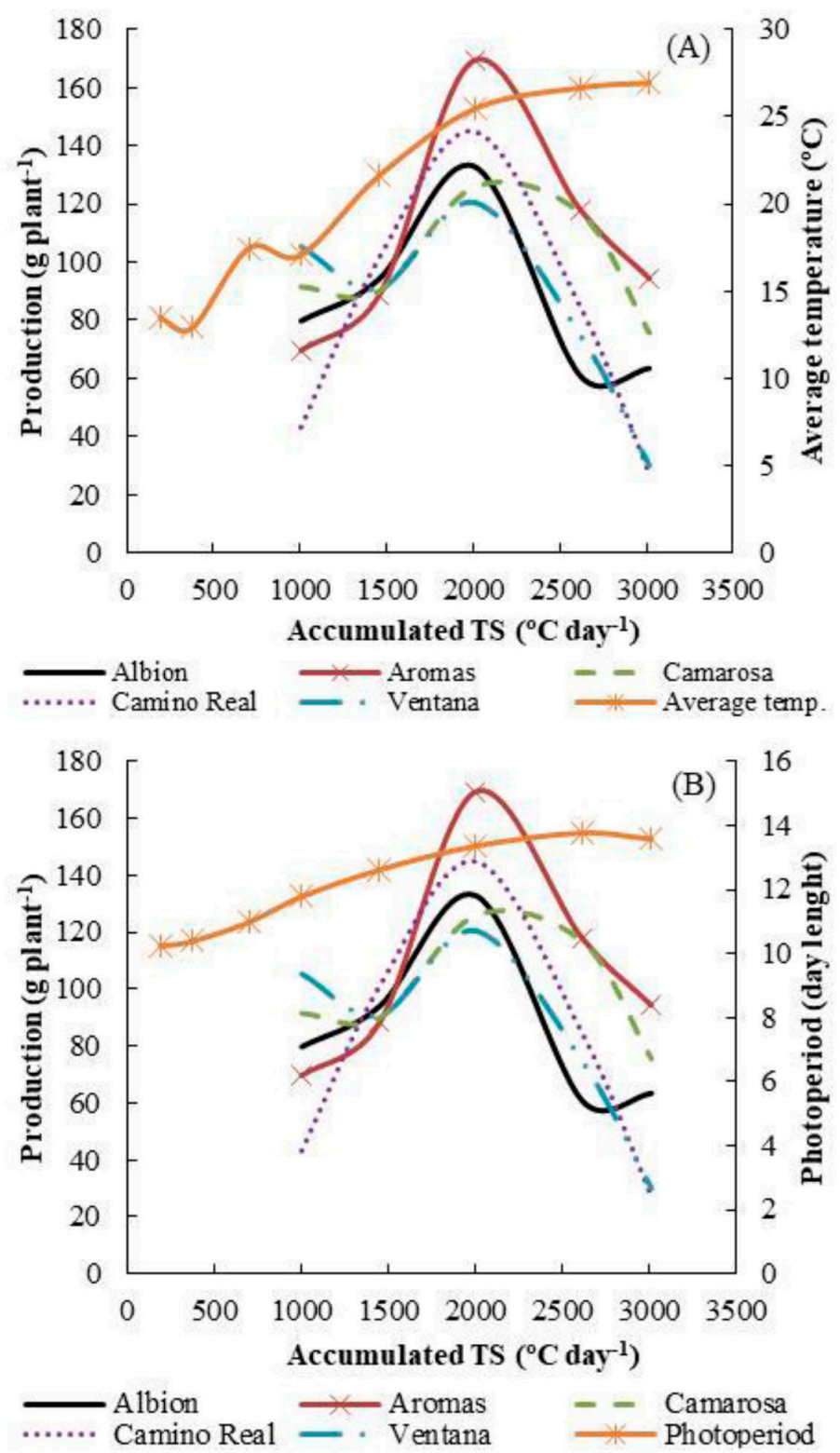

FIGURE 4 - Relation between the total production of strawberry fruits $\left(\mathrm{g} \mathrm{plant}^{-1}\right)$ intercropped with fig tree, the average temperature (A) and the photoperiod (B) with the accumulated thermal sum (TSa) during the plants growing period - Passo Fundo, 2009/2010 cycle. 


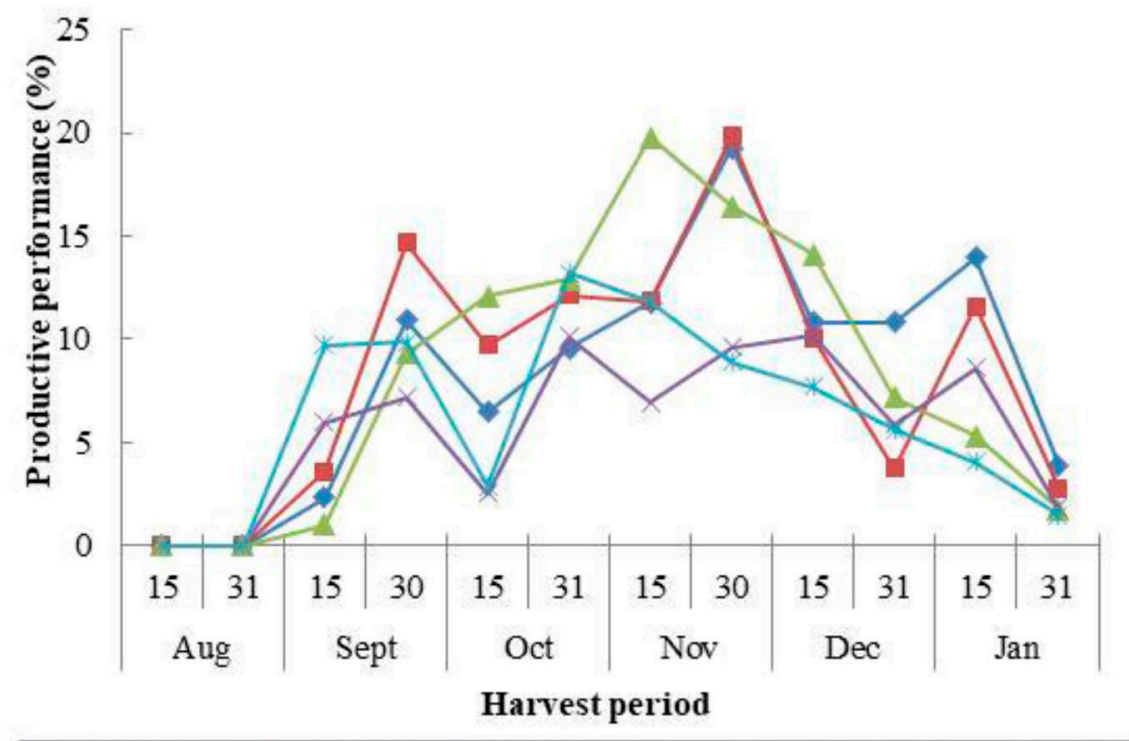

FIGURE 5 - Productive performance (\% in relation to the total harvest) during the harvest period of the seedlings cultivars from the Chile nursery intercropped with fig tree. Passo Fundo - 2009/2010.

\section{CONCLUSION}

Cultivars of strawberry show distinct production peaks in an integrated environment with fig tree. In addition, there is a higher harvest percentage for all cultivars in November. Camarosa shows superiority in productive capacity, besides presenting several peaks and with prolonged cycle.

\section{REFERENCES}

ANTUNES, L.E.C.; REISSER JÚNIOR, C. Fragole, i prodottori brasiliani mirano all'esportazione in Europa. Frutticoltura, Bologna, v.69, n.2, p.60-65, 2007.

BRADFORD, E.; HANCOCK, J.F.; WARNER, R.M. Interactions of temperature and photoperiod determine expression of repeat flowering in strawberry. Journal of the American Society for Horticultural Science, Michigan, v.135, n.2, p.102107, 2010.

CALVETE, E.O.; NIENOW, A.A.; WESP C.L.; CESTONARO, L.; MARIANI F.; FIOREZA, I.; CECCHETTI, D.; CASTILhOS, T. Produção hidropônica de morangueiro em sistema de colunas verticais, sob cultivo protegido. Revista Brasileira de Fruticultura, Jaboticabal, v.29, n.3, p.524-529, 2007.
CAMPAGNOLO, M. A.; PIO, R.; DALASTRA, I. M.; CHAGAS, E. A.; GUIMARÃES, FRANCISCO, V.; DALASTRA, G. M. Sistema desponte na produção de figos verdes 'Roxo de Valinhos'. Ciência Rural, Santa Maria, v.40, p.25-29, 2010.

COHORT SOFTWARE. CoStat. Monterey, 2003. Disponível em: <www.cohort.com>.

CUNHA, G.R. Meteorologia: fatos e mitos. Passo Fundo: Embrapa-CNPT, 2003. 440p.

DALASTRA, I. M.; PIO, R.; CAMPAGNOLO, M. A.; DALASTRA, G. M.; GUIMARAES, V.F.; CHAGAS, E. A. Número de ramos na produção de figos verdes Roxo de Valinhos no Oeste do Paraná. Revista Brasileira de Fruticultura, Jaboticabal, v.33, n.3, p.1029-1034, 2011.

DANELUZ, S.; PIO, R.; CHAGAS, E. A.; BARBOSA, W.; OHLAND, T.; ELISA KOTZ, T. Propagação da figueira 'Roxo de Valinhos' por alporquia. Revista Brasileira de Fruticultura, Jaboticabal, v.31, n.1, p.285-290, 2009. 
DARROW, G.M. Interrelation of temperature and photoperiodism in the production of fruit-buds and runners in the strawberry. Proceedings of the American Society for Horticultural Science, Geneva, v.34, n.3, p.360-363, 1936.

GUIMARAES, A.G.; ANDRADE JÚNIOR, V.C.; ELSAYED, A.Y.A.M.; FERNANDES, J.S.C.; FERREIRA, M.A.M. Potencial produtivo de cultivares de morangueiro. Revista Brasileira de Fruticultura, Jaboticabal, v.37, n.1, p.112-120, 2015.

HANCOCK, J.F.; LUBY, J.J.; DALE, A.; CALLOW, P.W.; SERÇE, S.; EL-SHIEK, A. Utilizing wild Fragaria virginiana in strawberry cultivar development: Ineritance of photoperiod sensitivity, fruit size, gender, female fertility and diseases resistance. Euphytica, Netherlands, v.126, n.2, p.177-184, 2002.

KADIR, S.; SIDHU, G. Strawberry (Fragaria $\mathrm{x}$ ananassa Duch.) growth and productivity as affected by temperature. HortScience, Manhattan, v.41, n.6, p.1423-1430, 2006.

MENDONÇA, H.F.C.; COSTA, R.C.; DECOSTA, L.A.; CALVETE, E.O.; CECATTO, A.P.; CHAVARRIA, G. Filocrono do morangueiro cultivado em diferentes densidades no substrato. p.233. In: CONGRESO ARGENTINO DE HORTICULTURA, 33., SIMPOSIO DE FRUTILLA, 1., 2010, Rosário. Anais... 520 p.

MENDONÇA. H.F.C. Produção e qualidade de morangos em cultivo protegido consorciado com a figueira. 2011. $112 \mathrm{f}$. Dissertação (Mestrado em Agronomia) - Faculdade de Agronomia e Medicina Veterinária, Universidade de Passo Fundo, Passo Fundo, 2011.
NIENOW, A.A.; CHAVES, A.; LAJÚS, C.R.; CALVETE, E.O. Produção da figueira em ambiente protegido submetida a diferentes épocas de poda e número de ramos. Revista Brasileira Fruticultura, Jaboticabal, v.28, n.3, p.421-424, 2006.

NISHIYAMA, M.; KANAHAMA, K. Effects of photoperiod and temperature on flower bud initiation in day-neutral and everbearing strawberries. Acta Horticulturae, The Hague, v.567, p.253-255, 2002.

NISHIYAMA, M., KANAHAMA, K. Effect of temperature and photoperiod on the development of inflorescences in everbearing strawberry (Fragaria $\times$ ananassa Duch.) plants. Acta Horticulturae, The Hague, v.514, p.261-267, 2000 .

OLIVEIRA, R.P.; SCIVITTARO, W.B.; CASTRO, L.A.S. Novas cultivares de morangueiro para a região de Pelotas. Pelotas: Embrapa Clima Temperado, 2007. $23 \mathrm{p}$.

SØNSTEBY, A.; HEIDE, O. M. Long-day control of flowering in everbearing strawberries. Journal of Horticultural Science and Biotechnology, Norway, v.82, n.6, p.875-884, 2007.

SØNSTEBY, A.; HEIDE, O. M. Temperature responses, flowering and fruit yield of the Junebearing strawberry cultivars Florence, Frida and Korona. Scientia Horticulturae, New York, v.119, p.49-54, 2008.

VERHEUL, M.J.; SONSTEBY, A.; GRIMSTAD, S.O. Interactions of photoperiod, temperature, duration of short-day treatment and plant age on flowering of Fragaria $\mathrm{x}$ ananassa Duch. cv.Korona. Scientia Horticulturae, New York, v.107, n.2, p.164-170, 2006. 